\title{
Reduction of electricity cost in public administration through a distributed generation strategy
}

\author{
Vinicius Cypriano Doelinger Assad ${ }^{1}$, Oureste Elias Batista ${ }^{1}$, Francisco Bernardes Neto ${ }^{1}$, Murillo Cobe \\ Vargas $^{1}$, Tatiana Saviato Macedo ${ }^{1}$ \\ ${ }^{1}$ Department of Electrical Engineering \\ Ufes, Universidade Federal do Espirito Santo \\ Campus of Vitória - ES, Brazil
}

e-mail: viniassad@gmail.com, oureste.btatista@ufes.br, francisco.bernardes@aluno.ufes.br, murillovargas@gmail.com, saviato@gmail.com

\begin{abstract}
The use of distributed generation as an alternative to reduce energy costs in the city hall of Vitória, capital of state of Espirito Santo in Brazil, is proposed in this paper. Photovoltaic solar energy was considered and the system sizing was carried out based on the total cost of eletricity in 2016 (available at the City's Transparency Website), resulting in a system with a total power of $78 \mathrm{MW}$. The financing scenarios were analyzed for acquisition of the system scaled with a horizon of 25 years. The results of the economic-financial analysis indicate that the investment is advantageous for the municipality and can bring great returns to the society.
\end{abstract}

\section{Key words}

Distributed generation, photovoltaic energy, economic viability analysis.

\section{Introduction}

Environmental sustainability policies, increasingly relevant to the planet's ecosystems, have been encouraging greater participation of renewable sources in the energy grid of the world's largest economies. In 2016, global demand for grid connected systems grew by $50 \%$ over the previous year, reaching $76.1 \mathrm{GW}$ installed, compared to 51.2 GW in 2015 [1].

The Public Administration, excluding electricity consumption with public services and public lighting, that is, considering only consumption of consumer units and considering the following subclass: Federal, State or District and Municipal public power. The consumption of Public Administration in 2015 was $15.186 \mathrm{GWh}$ with a total of 554.237 consumer units [2].

In 2012, the National Electric Energy Agency (Aneel) published Normative Resolution (RN) $\mathrm{n}^{\mathrm{o}} 482$, which established the general conditions for the access of distributed generation to the electric energy distribution systems, the tariff compensation system, among other measures (net metering) [3].

In the year of 2015, RN $n^{\circ} 687$ was published, an amendment to RN 482/2012, which increased the term for the use of energy credits, procedures for requesting access and changed the limits of micro and mini distributed generation: microgeneration was limited to installed capacity of $75 \mathrm{~kW}$ and minigeneration for installed power exceeding $75 \mathrm{~kW}$ and less than or equal to $5 \mathrm{MW}$ for qualified cogeneration or for other renewable energy sources [4].

In the one-year period, the number of connections in Brazil increased from 2.872 to 10.561 , that is, an increase of $368 \%$, shown in Figure 1. In the same way, as shown in Figure 2, the total installed power of distributed generation was $114.7 \mathrm{MW}$, corresponding to an increase of $159 \%$ in relation to the same previous period and $599 \%$ in relation to the month of December 2015 [5].

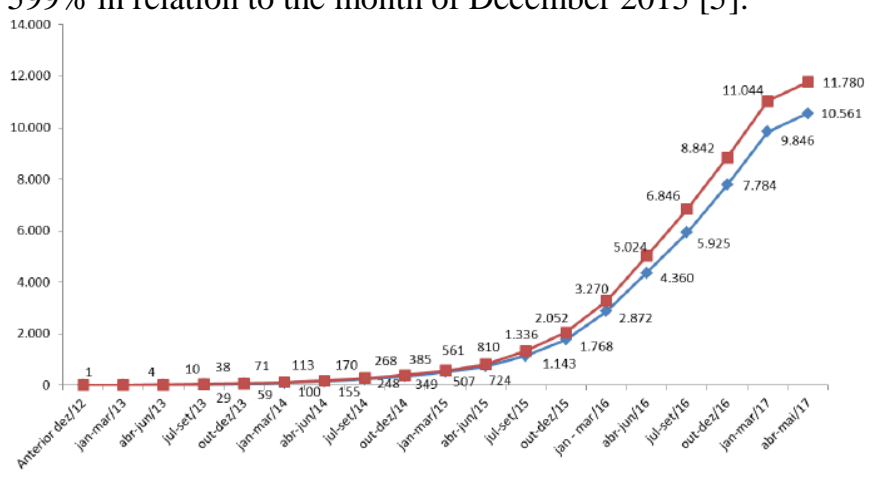

Fig. 1. Total number of connections of consumer units with distributed generation in Brazil up to the year 2017

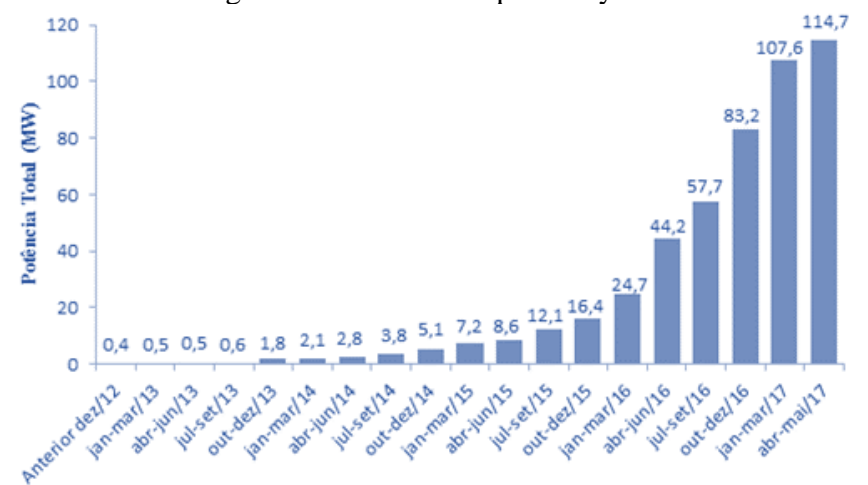

Fig. 2. Total installed power of micro and mini generation in Brazil until 2017 
Of the total installations, $99 \%$ use the solar photovoltaic source as the primary generation of their system [5]. This total corresponds to $80 \%$ of the total power installed in Brazil. Regarding consumer participation, the residential is in first place with $79,5 \%$ and the government in fourth place with $0,8 \%$ of participation, shown in Figure 3 [5].

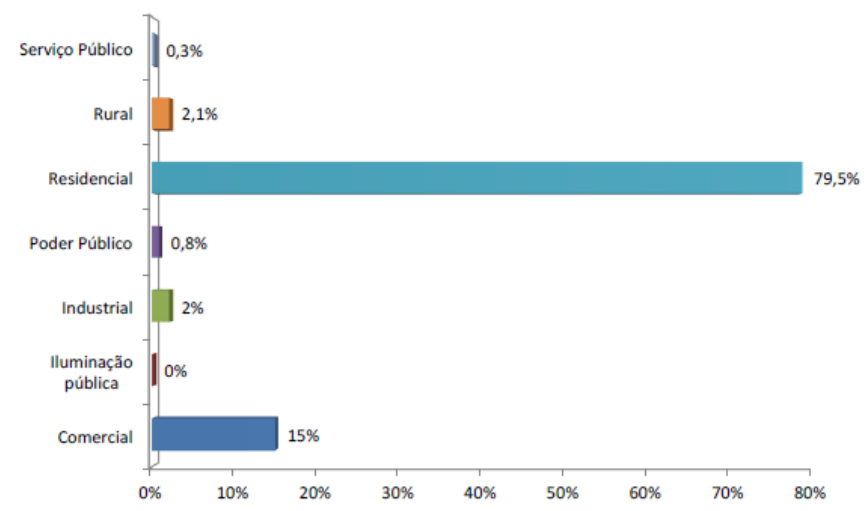

Fig. 3. Consumption category of micro and mini generation in Brazil up to 2017

Figure 4 shows Aneel's projection for total installed power up to the year 2024. This projection considers a growth of $2.700 \%$ in relation to the year 2017 .

This situation refers to a new scenario in which the solar photovoltaic source is more prominent, motivated by the excellent radiation rates in Brazil, public incentive policies and decreased values for the acquisition of the necessary equipment.

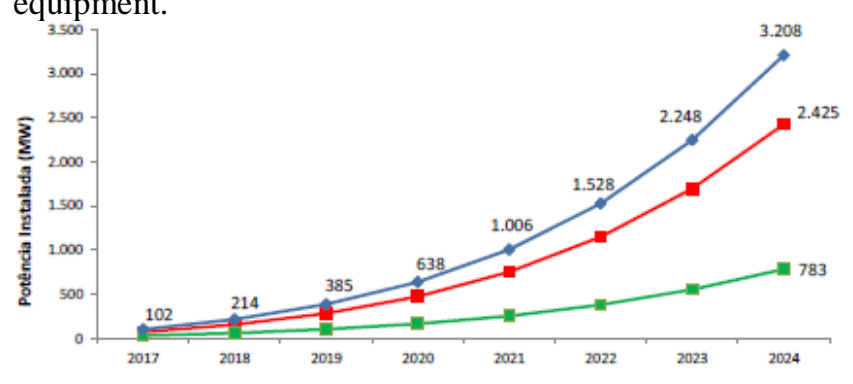

Fig. 4. Projected installed power for the year 2024

\section{Photovoltaic generation in the State of Espirito Santo}

The State of Espirito Santo (ES), located in the southeastern region of Brazil, has an annual average solar radiation index of 4,80 to $5,30 \mathrm{kWh} / \mathrm{m}^{2} /$ day, with a maximum seasonal average in the spring period $(6,30$ $\mathrm{kWh} / \mathrm{m}^{2} /$ day) and the minimum in the fall period $(3,70$ $\mathrm{kWh} / \mathrm{m}^{2} /$ day) [6].

Considering the inclined plane, the average annual values of global solar radiation vary from 5,07 to 5,58 $\mathrm{kWh} / \mathrm{m}^{2} /$ day and for the seasonal average maximum of $6,07 \mathrm{kWh} / \mathrm{m}^{2} /$ day (summer) and minimum of 4,57 $\mathrm{kWh} / \mathrm{m}^{2} /$ day (autumn) [6], being February and June the months with maximum and minimum radiation, respectively.

ES State has 502 consumer units connected to the grid through photovoltaic microgeneration, totaling 1,6 MW installed $(0,10 \%$ of total installed capacity in the ES), of which 373 were carried out during 2016 [7], as shown in Figure 5.

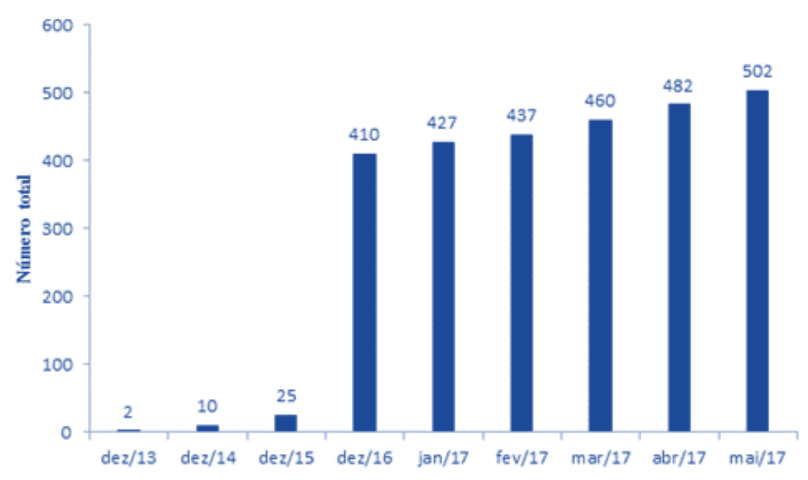

Fig. 5. Number of microgeneration connections in ES

\section{Analysis of economic viability}

\section{A. The proposal}

Considering the proposed scenario, this paper presents an investment proposal for the municipality of Vitória (PMV) that aims to reduce electricity costs through a strategy of installing photovoltaic panels, using the legal provisions of distributed generation.

This installation would supply $90 \%$ of the electricity consumed by three municipal administrative departments, which together accounted for $80 \%$ of the consumption in 2016. The residual percentage $(10 \%)$ would continue to be paid to the concessionaire as a contracting of minimum demand, rate of availability, taxes and tariffs. Photovoltaic solar energy would be responsible for compensating $90 \%$ of the electric energy consumed.

This proposal aims to demonstrate that investments in solar energy, in addition to being resonant with current environmental sustainability policies, can be considered as a driver of the public economy, since they would alleviate expenses with electricity and free the budget of own resources that can be applied to other services or projects of interest to society.

This type of initiative is not new in Brazil [9] [10]. However, the actions found are smaller and isolated. The study shows that a larger investment, interpreting distributed generation as investment, energy consumption as part of resource management, with adequate budget control and with coherent planning, can leverage attractive results for society.

\section{B. System Sizing}

The total power rating of the system was based on the electricity costs of the PMV Transparency Portal based on the year 2016 .

The electricity costs were separated by PMV with the municipal administrative departments. Figure 6 shows that about $80 \%$ of the total spent in the year is concentrated in administration (15 administrative units), health (29 health posts/stations) and education (102 schools) and corresponds to U\$ 3.212.373,52 [8]. 


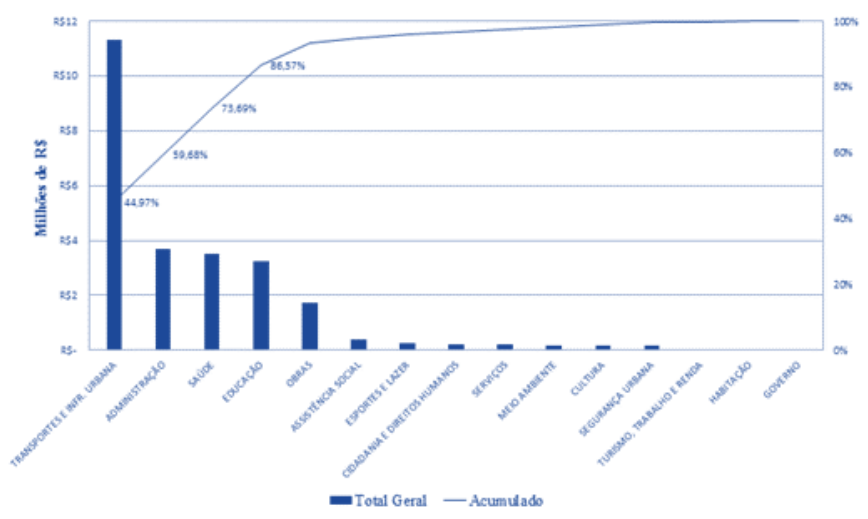

Fig. 6. Electricity costs per municipal administrative departments, year 2016

To estimate the total annual consumption, it is necessary to divide the amount spent by the average tariff charged by the local utility (EDP Brazil/ES) in the year 2016. Therefore, the average tariff charged for the B1 group (Commercial and residential consumer - until $75 \mathrm{~kW}$ ) was considered as U\$ $0,23 / \mathrm{kWh}$ (including the incidence of Brazil taxes - ICMS, PIS, COFINS and public lighting). Thus, there is a total of $13.974 .296 \mathrm{kWh} /$ year of electricity consumption.

The photovoltaic system was designed to supply $90 \%$ of the total annual consumption (12.576.296 kWh /year).

In order to optimize the efficiency of the system, standardize the facilities and respect the microgeneration limit, it was considered a photovoltaic kit with a total power of $78 \mathrm{~kW}$, consisting of inverters, photovoltaic modules, metallic installation structures, electrical components, connectors, with an average generation capacity of $10.647 \mathrm{kWh} /$ month with a value of U\$ $72.488,80 / \mathrm{kit}$. The cost with design and installation of the panels is equal to U\$ 9.455,03/kit.

In order to supply monthly PMV consumption (1.048.072 $\mathrm{kWh} / \mathrm{month}), 100 \mathrm{kits}$ of $78 \mathrm{~kW}$ are needed, totaling a power of $78 \mathrm{MW}$ and a total investment of U\$ 7.248.880,36.

\section{Indicators for economic-financial feasibility analysis of projects}

For the financial feasibility study and decision making, some investment indicators will be used, since only an economic study can confirm the feasibility of technically correct projects. There are Three basic and most used methods of investment analysis: Net Present Value Method (NPV), Internal Rate of Return (IRR) method and Equivalent Uniform Annual Value Method (EUAV) [11]. When analyzing an investment proposal, one must consider the fact that one is missing the opportunity to receive returns by applying the same capital in other projects. The new proposal to be attractive must yield at least the interest rate equivalent to the profitability of current and low risk applications. The Minimum Attractiveness Rate (MAR) is chosen by the company in a way that best applies to its investment policy [11].

The discounted payback considers the value of the time investment because it uses a discount rate to check the number of periods in which the project recovers the initial amount invested. Normally, this discount rate used is the
MAR, which is determined by the investor as a parameter for the remuneration of its capital [12].

The EUAV consists in finding the annual uniform series equivalent to the cash flow of the investments to the MAR, that is, the uniform series equivalent to all the costs and revenues for each project is calculated using the MAR. The best project is the one with the highest positive balance [11].

The NVP measure is obtained by the difference between the present value of the net cash benefits forecast for each period of the project duration horizon and the present value of the investment [13].

This method is as simple as the EUAV. The only difference is that, instead of distributing the initial investment during its lifetime (capital recovery cost), one must now calculate the Present Value of the other terms of the cash flow to add them to the initial investment of each alternative. We choose the alternative that presents better NPV. The rate used to discount the flow (bring to the present value) is the MAR [11].

The IRR of an investment is the required rate of return which, when used as the discount rate, results in NPV equal to zero. Thus, when the NPV is zero, the economic break-even point of the project is found. In this way, the IRR represents the interest rate at which the present value of the cash inflows resulting from the project equals the present value of the disbursements of the project [11].

The Profitability Index (PI) is a variant of NPV. The PI is determined by dividing the present value of net cash benefits by the present value of capital outlays. It indicates, in terms of Present Value, how much the project offers of return for each monetary unit invested [13].

\section{Results}

The financing calculation considered three different scenarios with different financial institutions. The first scenario considers that the project will be financed by the specific credit line for investments in infrastructure and energy offered by the World Bank whose maximum interest rate charged is $1 \%$ per year. The second scenario considers that the resources will be obtained from the National Bank for Economic and Social Development (BNDES) at an average rate of $7 \%$ per year. The latter scenario considers the average interest rate practiced by commercial banks in Brazil, currently at $14 \%$ per year. Assuming that public administration has no interest of generate profit, the MAR was defined as the interest rate itself for each analysed scenario. Table 1 shows the results of the analysed scenarios.

Table I. - Results economic financial analysis

\begin{tabular}{|c|c|c|c|c|c|c|c|c|}
\hline \multirow{2}{*}{$\begin{array}{l}\text { Interest rate } \\
\text { financing }\end{array}$} & \multicolumn{8}{|c|}{ Economic and financial indicators } \\
\hline & MAR & & NVP & IRR & & EUAV & PI & $\begin{array}{c}\text { Payback } \\
\text { (years) }\end{array}$ \\
\hline $1 \%$ p.y & $\%$ & $\$$ & $55.621 .547,72$ & $38 \%$ & $\$$ & $2.525 .593,90$ & $790 \%$ & 2,6 \\
\hline $7 \%$ p.y & $7 \%$ & $\$$ & $26.019 .093,27$ & $30 \%$ & $\$$ & $2.232 .711,85$ & $388 \%$ & 2.9 \\
\hline $14 \%$ p.y & $14 \%$ & $\$$ & $12.371 .554,42$ & $22 \%$ & $\$$ & $1.800 .041,47$ & $206 \%$ & 3,4 \\
\hline
\end{tabular}

Table 1 shows the results of the chosen scenarios with their respective indicators. Noting the worst scenario, which already indicates that the investment is 
advantageous for the municipality, with the IRR greater than the MAR, fast payback, positive NVP and the EUAV of U\$ 1.800.041,47, that is, indicates that if there were no initial investment, it would be as if the PMV was collecting this amount annually.

\section{Conclusion}

With the considerable increase in the adhesion to microgeneration and the dominant presence in the National Interconnected System (SIN), investments in electricity generation through photovoltaic systems are increasingly advantageous in Brazil.

This present study used data from the PMV transparency Portal, referring to the electricity costs that each public administration unit consumed throughout 2016. The municipal administration departments representing the largest share of current consumption, administration, health, and education were selected, excluding the costs of tied resources (public lighting), third party services and maintenance.

Established initial considerations and a kit standard to be used, it was possible to size a photovoltaic power generation system that would meet $90 \%$ of PMV's annual electricity consumption demand.

It is concluded from the economic-financial analysis of the study proposal that the investment is very advantageous for the municipality, even if the worst financing scenario ( $14 \%$ per year) is chosen. Even so, the returns will be advantageous, reflecting directly in the release of the own resources budget, that is, resources that can be used to improve services provided to the population and investments in infrastructure.

\section{References}

[1] SUN \& WIN Energy. available in: <http://www.sunwindenergy.com/photovoltaics/global-solarpower-demand-grows-nearly-50-2016-europe-drops.> Accessed in: $21 \mathrm{Jul} 2017$.

[2] Empresa de Pesquisa Energética (EPE). Anuário Estatístico de Energia Elétrica 2016. available in: < http://www.epe.gov.br/AnuarioEstatisticodeEnergiaEletrica/Form s/Anurio.aspx>. Accessed in: 20 Set 2017

[3] Agência Nacional de Energia Elétrica (ANEEL). Resolução Normativa $\mathrm{n}^{\mathrm{o}}$ 482/2012. available in: <http://www2.aneel.gov.br/cedoc/ren2012482.pdf >. Accessed in: 20 Jul 2017.

[4] Agência Nacional de Energia Elétrica (ANEEL). Resolução Normativa $\mathrm{n}^{\circ}$ 687/2015. available in: < http://www2.aneel.gov.br/cedoc/ren2015687.pdf>. Accessed in: $20 \mathrm{Jul} 2017$.

[5] Agência Nacional de Energia Elétrica (ANEEL). Nota Técnica 56/2017. available in: < http://www.aneel.gov.br/documents/656827/15234696/Nota+T\% C3\%A9cnica_0056_PROJE\%C3\%87\%C3\%95ES+GD+2017/38 cad9ae-71f6-8788-0429-d097409a0ba9>. Accessed in: $20 \mathrm{Jul}$ 2017.

[6] Atlas Solar Espírito Santo. available in: <http://www.aspe.es.gov.br/download/Energia_Solar_ES.pdf>. Accessed in: 19 Jul 2017.

[7] Agência de Regulação de Serviços Públicos do Espírito Santo (ARSP). Informações Energéticas Maio e Junho de 2017. available in: <https://arsp.es.gov.br/boletins-e-balancosenergeticos>. Accessed in: 19 Jul 2017.
[8] Portal da Transparência de Vitória. available in:< http://transparencia.vitoria.es.gov.br/>. Accessed in: $20 \mathrm{Jul}$ 2017.

[9] Prefeitura inaugura primeira escola de tempo integral a funcionar com energia solar. available in: < https://www.brasil247.com/pt/247/ceara247/283152/Prefeiturainaugura-primeira-Escola-de-Tempo-Integral-a-funcionar-comenergia-solar.htm>. Accessed in: $20 \mathrm{Jul} 2017$.

[10] Prefeitura inaugurou a primeira usina de energia solar de Boa Vista. available in: < http://boavista.rr.gov.br/noticias/2017/03/prefeitura-inauguroua-primeira-usina-de-energia-solar-de-boa-vista. Accessed in: 21 Jul 2017.

[11] CASAROTTO FILHO, Nelson. Analise de investimentos: matemática financeira, engenharia econômica, tomada de decisão, estratégia empresarial. 2000.

[12] SANVICENTE, Antônio Zoratto. Administração Financeira. 1987.

[13] ASSAF NETO, Alexandre. Finanças corporativas e valor. 2006. 